\title{
EXECUTIVE FUNCTIONS IN CONNECTION WITH THE DEVELOPMENT OF BILINGUAL SPEECH OF SENIOR PRE-SCHOOLERS
}

\author{
Vera Khotinets, Oksana Kozhevnikova \\ Udmurt State University, Russian Federation
}

\begin{abstract}
The paper analyzes the topical problems of bilingualism effects and its benefits in cognitive control of speech activity in two or more languages. In psychological science, there is insufficient research on the cognitive regulation of bilinguals in connection with speech development in the first and the second languages especially of children in the pre-school period that is characterized by a leap in speech development, functional restructuring, and expansion of regulatory resources. There is scarcity of works related to the specifics of cognitive control of speech activity of bilingual children with different levels of language proficiency and usage. The research aim was to examine the regulatory functions coordinative and subordinative preschool bilinguals in actualization of speech activity in their native and Russian languages. The study involved 65 bilingual children (Udmurt/Russian) aged 5.7 to 7.5 from preschool institutions of the Udmurt Republic: children with coordinative bilingualism ( $n=32,15$ boys, 17 girls) equally speaking both languages and subordinative bilingualism with significant interference of the dominant language (mother tongue) while using the other ( $n=33,17$ boys, 16 girls). Data collection materials were presented to the subjects in two versions: in the native and Russian languages. Theresearch techniques used in the study included: the Stroop Color and Word Test, "The Classification of Geometric Figures" "Verbal memory" "Visual Memory" "Verbal antonyms," "Verbal classifications," "Speech development (correction, restoration, completion of statements)" tests. The methods of mathematical statistics - descriptive statistics, the Mann-Whitney U-test, the Spearman correlation coefficient were used in data analysis. Based on the results of the empirical study, the fact of the absence of significant differences in the cognitive regulation of speech activity in the native language of preschoolers with coordinative and subordinative bilingualism was established. The obtained research results confirm astatement of Vygotsky's cultural-historical theory that speech development causes changes in the development of regulatory functions. The practical significance of the findings is reinforced by the escalation of emigration processes in most countries increasing the professional responsibility of educators in supporting diversity and preserving the uniqueness of the childhood as an important stage in the general development of a person.
\end{abstract}

Keywords: cognitive flexibility, coordinative and subordinative bilingualism, executive functions, interference control, preschool age, speech development, udmurts, working memory. 


\section{Introduction}

Scientific interest in the effects of bilingualism and multilingualism is constantly increasing and focuses on the issues of benefits in cognitive control of speech activity in two or more languages (Zhou \& Krott, 2016). The widely used concept of "executive functions" is recently complemented by Russian scholars with such terminology as "control functions" associated with behavior change management (Nikolaeva \& Vergunov, 2017) and "regulatory functions" providing targeted problem solving and adaptive behavior in modified circumstances (Veraksa et al., 2019). As a rule, regulatory functions that enhance cognitive processes include inhibitory control, working memory (verbal and non-verbal) and cognitive flexibility. Inhibitory control blocks and suppresses irrelevant verbal and non-verbal information (Bialystok et al., 2004). Cognitive flexibility ensures plasticity of cognitive activity in alignment with performance requirements and subject priorities (Nikolaeva \& Vergunov, 2017). Working memory updates verbal and non-verbal information in the linguistic context of the target language (Samuel et al., 2018). Along with that, bilinguals demonstrate difficulties associated with cognitive linguistic processing: low fluency of speech, a low rate of lexical access, a smaller volume of passive vocabulary in both languages, etc. (Bialystok et al., 2014; Medvedeva et al., 2017; Kozhevnikova \& Khotinets, 2021). In addition, some scholars found no differences between bilingual and monolingual subjects due to the wide age range of research samples (Bialystok, 2017; Dick et al., 2019).

The most important contribution to solving the above-mentioned problem is the research results that demonstrate the choice of strategies and ways to solve conflicting objectives in the absence of differences in performance between bilingual and monolingual children. A fundamental distinction is that bilingual children constantly demonstrate compromises between speed and accuracy while performing complicated competing tasks. It is argued that differences in cognitive problem-solving strategies are caused by using two (or more) language systems that affect cognitive processing (Struys et al., 2018). According to Bialystok and Craik (2010), the mechanism involved in resolving a potential conflict between two language systems and choosing a target language is general executive control. The need to resolve the conflict in language choice improves regulatory functions which, in turn, provides additional advantages in solving complex verbal and non-verbal tasks (Emmorey et al., 2008). At the same time, critics of bilingual advantages point out that many studies have serious methodological issues with internal and external validity, the inability to compare results due to the multi-determination of bilingual children's cognitive development that is determined by various combinations of sociocultural 
variables (distance of cultures and similarity of languages), educational systems and models, educational space and conditions of socialization / individualization of the child in the linguistic environment, socio-economic status of the family, type of bilingualism of the child, etc. (Haft et al., 2019).

In modern psychology, the problem of correlation of speech and regulatory functions in preschool age is associated with solving the issue of the direction of their correlation. For the most part, it is empirically confirmed that the development of regulatory functions leads to progressive speech development. This result is consistent with the idea of gradual increase in the cognitive capabilities of children through the development of regulatory functions. Other studies conducted in the context of Vygotsky's cultural-historical theory demonstrate the opposite pattern: speech development causes changes in the development of regulatory functions as children with speech deficits have significantly lower results in the development of regulatory functions in comparison with normative children. Thus, the meta-analysis of studies shows the bidirectional correlation of speech development indicators with components of regulatory functions (Veraksa et al., 2019; Khotinets \& Medvedeva, 2021). The problem of linguistic cognitive processing within interaction of two (or more) language systems and linguistic divergence of syntactic structures is also topical today. Bilingual children's cognitive regulation is explored in the context of the necessity to choose a language, the effectiveness a particular language system usage for cognitive activity implementation. Other important issue is the specifics of cognitive control of speech activity of bilingual children in the preschool period that is characterized by a leap in speech development, functional restructuring, and expansion of regulatory resources.

The aim of this study is to analyze the regulatory functions of preschool children with coordinative and subordinative bilingualism in speech activity in their native and Russian languages. The following research tasks are put forward and carried out:

1. To determine the significance of the indicators of regulatory functions in speech activity in native and Russian languages among preschool coordinative and subordinative bilinguals.

2. To identify the correlation of regulatory functions with the development of bilingual speech in groups of preschool coordinative and subordinative bilinguals.

\section{Method}

\section{Sampling}

The study involved 65 bilingual children (Udmurt and Russian) aged 5.7 to 7.5 years $(M=6.53$, Med $=6.5)$ from preschool institutions of 
the Udmurt Republic. There are children with coordinate bilingualism who equally speak both languages ( $N=32,15$ boys, 17 girls) and subordinative bilingualism with significant interference of the dominant language (mother tongue) while using the other ( $N=33,17$ boys, 16 girls). The fact that boys and girls in both samples did not differ in their regulatory functions confirms the results of several studies of asynchronous and heterochronous development of regulatory functions within the child population (Best et al., 2009). However, there are gender differences in speech development: girls in both groups demonstrated higher results than boys $(p \leq 0.05)$ due to the accelerated rate of their maturation in the preschool period (Lynn, 1999).

Parents of bilingual preschoolers were informed about the means and methods of interaction with their children. The research subjects were homogeneously selected by socio-economic status of the family (middle average income, parents' education level (higher education in groups with coordinative bilingualism $-37 \%$, subordinative bilingualism $-34 \%$ ), housing conditions in accordance with established standards, parental involvement in the child's educational process, activity of interaction and cooperation with a preschool institution. Based on the results of a written survey of parents about the language situation in the family (Medvedeva et al., 2017), only bilingual children using mainly Udmurt language at home were included in the research sample. In a preschool institution, education process was conducted in a balanced manner in both Udmurt and Russian.

\section{Data collection}

At the stage of collecting empirical data, standardized methods were used in two formats: in native and Russian languages. To detect the level of interference control, the Stroop Color and Word Test was implemented (Holodnaya, 2004). When children were performing each of the three tasks the time was fixed. Then the difference between the time spent naming the color of the word (task 3) which does not correspond to its meaning and the time spent naming the color of the square (task 2) was calculated. The greater the time difference, the larger the interference effect and the lower the level of interference control development (control rigidity). To study cognitive flexibility, the research technique "The Classification of Geometric Figures" was used (Abramova, 1999). The main task was to classify cards in accordance with three distinguishing features. The next task was to independently solve a similar problem of classifying another set of figures according to three features in a verbal form. The technique allows to measure cognitive flexibility in the transition from one feature (form) to another (color) in the process of classifying. 
To measure working memory (verbal and visual) and the level of speech development, a set of tasks developed by Yasyukova (2008) was used: "Verbal memory" "Visual Memory" "Verbal antonyms," "Verbal classifications," "Language Proficiency (correction, restoration, completion of statements)". Mathematical and statistical analysis of the data using the IBM SPSS Statistics 22.0 for Windows software package included: descriptive statistics (to calculate the main characteristics of data distribution), the Mann-Whitney $U$ test (a nonparametric test to identify significant differences between indicators); the Spearman correlation coefficient (to detect correlations between variables).

\section{Results}

The summarized results of the research are presented in the Tables 1-4. The specificity of regulatory functions of senior preschool coordinative and subordinative bilinguals was revealed based on statistical analysis of the research data using the Mann-Whitney U-test (Table 1 and Table 2).

Table 1. Descriptive Statistics and Statistical Assessment of Differences for Study Variables (preschool coordinative and subordinative bilinguals' speech activity in native language)

\begin{tabular}{|c|c|c|c|c|c|c|}
\hline \multirow[t]{2}{*}{ Variable } & \multicolumn{2}{|c|}{$\begin{array}{l}\text { Preschool children } \\
\text { with coordinative } \\
\text { bilingualism } \\
(n=32)\end{array}$} & \multicolumn{2}{|c|}{$\begin{array}{l}\text { Preschool children } \\
\text { with subordinative } \\
\text { bilingualism } \\
(n=33)\end{array}$} & \multirow[t]{2}{*}{ U-test } & \multirow{2}{*}{$\begin{array}{l}\text { The level } \\
\text { of statis- } \\
\text { tical sig- } \\
\text { nificance } \\
\text { (p-value) }\end{array}$} \\
\hline & M & $S D$ & M & $S D$ & & \\
\hline $\begin{array}{l}\text { 1. Interfer- } \\
\text { ence control }\end{array}$ & 0.835 & 0.584 & 0.854 & 0.601 & 485.6 & 0.772 \\
\hline $\begin{array}{l}\text { 2. Cognitive } \\
\text { flexibility }\end{array}$ & 1.913 & 1.662 & 2.203 & 1.826 & 468.5 & 0.753 \\
\hline $\begin{array}{l}\text { 3. Working } \\
\text { (verbal) } \\
\text { memory }\end{array}$ & 5.648 & 1.117 & 5.324 & 1.385 & 458.5 & 0.664 \\
\hline $\begin{array}{l}\text { 4. Working } \\
\text { (visual) } \\
\text { memory }\end{array}$ & 9.221 & 2.581 & 8.957 & 2.637 & 472.0 & 0.719 \\
\hline $\begin{array}{l}\text { 5. Speech } \\
\text { development }\end{array}$ & 13.002 & 2.435 & 13.112 & 3.926 & 463.3 & 0.678 \\
\hline
\end{tabular}


Table 2. Descriptive Statistics and Statistical Assessment of Differences for Study Variables (preschool coordinative and subordinative bilinguals' speech activity in Russian language)

\begin{tabular}{|c|c|c|c|c|c|c|}
\hline \multirow[t]{2}{*}{ Variable } & \multicolumn{2}{|c|}{$\begin{array}{l}\text { Preschool children } \\
\text { with coordinative } \\
\text { bilingualism } \\
(n=32)\end{array}$} & \multicolumn{2}{|c|}{$\begin{array}{l}\text { Preschool children } \\
\text { with subordinative } \\
\text { bilingualism } \\
(n=33)\end{array}$} & \multirow[t]{2}{*}{ U-test } & \multirow[t]{2}{*}{$\begin{array}{l}\text { The level } \\
\text { of statis- } \\
\text { tical sig- } \\
\text { nificance } \\
\text { (p-value) }\end{array}$} \\
\hline & $M$ & $S D$ & $M$ & $S D$ & & \\
\hline $\begin{array}{l}\text { 1. Interfer- } \\
\text { ence control }\end{array}$ & 0.841 & 0.590 & 2.395 & 0.685 & 323.3 & 0.012 \\
\hline $\begin{array}{l}\text { 2. Cognitive } \\
\text { flexibility }\end{array}$ & 1.907 & 1.653 & 2.912 & 2.041 & 351.0 & 0.049 \\
\hline $\begin{array}{l}\text { 3. Working } \\
\text { (verbal) } \\
\text { memory }\end{array}$ & 5.623 & 1.338 & 4.924 & 1.462 & 323.5 & 0.013 \\
\hline $\begin{array}{l}\text { 4. Working } \\
\text { (visual) } \\
\text { memory }\end{array}$ & 9.155 & 2.450 & 9.086 & 2.557 & 482.0 & 0.733 \\
\hline $\begin{array}{l}\text { 5. Speech } \\
\text { development }\end{array}$ & 13.537 & 2.698 & 8.372 & 3.8528 & 145.6 & 0.001 \\
\hline
\end{tabular}

The interconnections of regulatory functions with development of bilingual speech in groups of preschool coordinative and subordinative bilinguals were determined by correlation analysis methodology (Table 3 and Table 4).

Table 3. Correlations for Study Variables (preschool coordinative and subordinative bilinguals' speech activity in native language)

\begin{tabular}{|l|l|l|l|l|l|l|}
\hline Variable & $\begin{array}{l}\text { Bilingualism } \\
\text { type }\end{array}$ & $\mathbf{1}$ & $\mathbf{2}$ & $\mathbf{3}$ & $\mathbf{4}$ & $\mathbf{5}$ \\
\hline $\begin{array}{l}\text { 1. Interfer- } \\
\text { ence control }\end{array}$ & coordinative & 1 & 0.345 & 0.327 & 0.264 & $-0.349^{*}$ \\
\cline { 2 - 7 } & subordinative & 1 & 0.277 & 0.289 & 0.012 & -0.246 \\
\hline $\begin{array}{l}\text { 2. Cognitive } \\
\text { flexibility }\end{array}$ & coordinative & 0.345 & 1 & $-0.357^{*}$ & -0.276 & $-0.594^{* *}$ \\
\cline { 2 - 7 } & subordinative & 0.277 & 1 & -0.342 & 0.138 & $-0.480^{* *}$ \\
\hline $\begin{array}{l}\text { 3. Working } \\
\text { (verbal) } \\
\text { memory }\end{array}$ & coordinative & 0.327 & $-0.357^{*}$ & 1 & 0.263 & $0.382^{*}$ \\
\hline & subordinative & 0.289 & -0.342 & 1 & $0.440^{*}$ & $0.341^{*}$ \\
\hline $\begin{array}{l}\text { 4. Working } \\
\text { (visual) } \\
\text { memory }\end{array}$ & coordinative & 0.264 & -0.276 & 0.263 & 1 & 0.249 \\
\hline
\end{tabular}

Note. ${ }^{*} p<.05 . * * p<.01$ 
Table 4. Correlations for Study Variables (preschool coordinative and subordinative bilinguals' speech activity in Russian language)

\begin{tabular}{|l|l|l|l|l|l|l|}
\hline Variable & $\begin{array}{l}\text { Bilingualism } \\
\text { type }\end{array}$ & 1 & 2 & 3 & 4 & 5 \\
\hline \multirow{2}{*}{$\begin{array}{l}\text { 1. Interfer- } \\
\text { ence control }\end{array}$} & coordinative & 1 & 0.298 & 0.225 & 0.168 & $-0.352^{*}$ \\
\cline { 2 - 7 } & subordinative & 1 & -0.172 & -0.182 & 0.126 & 0.283 \\
\hline $\begin{array}{l}\text { 2. Cognitive } \\
\text { flexibility }\end{array}$ & coordinative & 0.298 & 1 & $-0.385^{*}$ & -0.278 & $-0.572^{* *}$ \\
\cline { 2 - 7 } & subordinative & -0.172 & 1 & -0.139 & 0.138 & -0.280 \\
\hline $\begin{array}{l}\text { 3. Working } \\
\text { (verbal) } \\
\text { memory }\end{array}$ & coordinative & 0.225 & $-0.385^{*}$ & 1 & 0.327 & $0.374^{*}$ \\
\cline { 2 - 8 } $\begin{array}{l}\text { 4. Working } \\
\text { (visual) } \\
\text { memory }\end{array}$ & subordinative & -0.182 & -0.139 & 1 & $0.365^{*}$ & 0.266 \\
\cline { 2 - 8 } & coordinative & 0.168 & -0.278 & 0.327 & 1 & 0.251 \\
\hline $\begin{array}{l}\text { 5. Speech } \\
\text { development }\end{array}$ & coordinative & $-0.352^{*}$ & $-0.572^{* *}$ & $0.374^{*}$ & 0.251 & 1 \\
\cline { 2 - 8 } & subordinative & 0.283 & -0.280 & 0.266 & 0.250 & 1 \\
\hline
\end{tabular}

Note. ${ }^{*} p<.05 .{ }^{* *} p<.01$

\section{Discussion}

Research results showing the specificity of regulatory functions of preschool coordinative and subordinative bilinguals when performing tasks in their mother tongue (Table 1) demonstrated no significant differences between all study variables. It was also found that bilingual children's speech in the native (Udmurt) language is at a medium level of development. The results obtained through using Russian-language techniques (Table 2) represent statistically significant differences in the following variables: interference control $(U=323.3 ; p=0.012)$, cognitive flexibility $(U=351.0 ; p=0.049)$, verbal memory $(U=323.5 ; p=0.013)$, speech development $(U=145.6 ; p=0.001)$. These findings are in compliance with numerous empirical studies proving that the necessity for increased cognitive control of bilingual children is associated with the co-activation of both languages and the need for linguistic processing in a target language which is not required for those who mainly use one (dominant) language (Bialystok \& Craik, 2010; Struys et al., 2018). Under equal operating conditions, to achieve rapid linguistic effectiveness, coordinative bilinguals are more demanding to the control system than those who prefer to speak one (native) language (Bialystok, 2017).

It should be specified that in the group of children with subordinative bilingualism, the mean value of speech development in Russian is in the low level when we speak about different types of interference: phonological 
(transfer of pronunciation skills of the Udmurt language into Russian), lexical (mixing similar words in the two languages) and grammatical (violation or deviation of grammatical norms of the Russian language due to the transfer of grammatical skills of the native language), as well as limited active vocabulary. Thus, the findings are consistent with the researchers' dominant position on speech problems of children with heritage bilingualism in preschool age (Ardila, 2012; Medvedeva \& Khotinets, 2018; Khotinets \& Salnova, 2020).

According to the results of correlation analysis of study variables in the group of preschool coordinative bilinguals (Tables 3 and 4), close correlations between speech development both in the native and Russian languages and indicators of regulatory functions (interference control $(p<0.05)$, cognitive flexibility $(p<0.001)$, speech memory $(p<0.05))$ were found. In the group of preschool subordinative bilinguals there were less intense and less close correlations of regulatory functions (cognitive flexibility ( $p<0.01)$, speech memory $(p<0.05)$ ) with speech development in their native language. In addition, there was a positive correlation between visual and verbal memory $(p<0.05)$ in the conditions of speech activity in Russian.

The results obtained in our empirical study can be explained through the idea that the need to simultaneously manage two active linguistic systems increases the cognitive load for regulating the interaction of these systems (Bialystok, 2017). From the point of view of modern network models of the mental lexicon, lexical access to languages in the network is activated automatically and simultaneously regardless of the language of communication. The emerging intra-and inter-lingual competition of nodes (structural elements of artificial neural networks) in the bilingual lexicon is carried out due to its resource capabilities (considering age, level of language proficiency, conditions of linguistic and cultural socialization) which ensure the regulation and execution of functioning processes (Li \& Farkas, 2002; Li et al., 2007). If the mother tongue dominates in the absence of inter-language competition and interference effects when fragments of the first language are directly "embedded" in the field of the second language, the resource of regulatory control decreases. In addition, in case of linguistic divergence of the syntactic structures of the two languages and a low level of proficiency in the second language, the prospect of actualizing it in the future weakens.

The revealed correlation between visual and verbal memory in the group of subordinative bilinguals in the context of speech activity in the second language can be explained in the following way: the apparent difficulty of speech activity increases cognitive load, in particular, required working memory (Bialystok et al., 2004; Bialystok et al., 2008; Fernandes 
et al., 2007; Just \& Carpenter, 1992; Michael \& Gollan, 2005; Rosen \& Engle, 1997). Most likely, the accumulation of regulatory potential in the actualization of speech in the second language of subordinative bilinguals is accompanied by a "reconfiguration" of memory modalities (Schneider \& Kozintseva, 2019).

\section{Conclusions}

A theoretical analysis of the research problem showed the ambiguity of positions in understanding the effects of bilingualism on the cognitive development of children and the insufficiency of its studying in the pre-school period which is characterized by a leap in speech development, functional restructuring, and expansion of regulatory resources. Based on the results of the empirical study, the fact of the absence of significant differences in the cognitive regulation of speech activity in the native language of preschool coordinative and subordinative bilinguals was established. Moreover, the advantages of coordinative bilingualism in performing tasks requiring blocking and suppression of irrelevant verbal and non-verbal information (interference control), plasticity of cognitive activity in connection with changing performance requirements and subject priorities (cognitive flexibility), actualization of verbal and non-verbal information (working memory) in the context of speech activity using the means of the second language were revealed. At the same time, in the group of preschool coordinative bilinguals, close correlations between speech development both in the first and second languages and the indicators of regulatory functions were described. Preschool subordinative bilinguals demonstrate less intense and less close connections of regulatory functions with speech development in their native language. The obtained research results confirm a statement of Vygotsky's cultural-historical theory that speech development causes changes in the development of regulatory functions. Previous studies conducted by Russian scholars have proved that children with speech deficits show significantly lower results in the development of regulatory functions in comparison with normative children. However, in modern psychology, the problem of the connection of speech and regulatory functions in the aspect of solving the issue of the direction of their correlation remains unresolved.

As a perspective of further research, we consider the construction of a model for the development of regulatory functions considering various scenarios for the mastery of languages (first, second, third) by children of different ages: simultaneous, consecutive, early, later language education with the aim of constructing psychological and pedagogical technologies for the development and support of bilingual children at different 
age periods. So, the problem of multi-determination of the development of cognitive structures of bilingual children in connection with contemporary socio-cultural changes pre-empts the choice of new methodological strategies in exploring individual resources of subjective regulation in the context of language socialization. The practical significance of the research results is reinforced by the escalation of emigration processes in most countries increasing the professional responsibility of educators in supporting diversity and preserving the uniqueness of the childhood as an important stage in the general development of a person.

\section{References}

Abramova, G. S. (1999). Applied developmental psychology. Moscow Akademia (In Russ.)

Ardila, A. (2012). Advantages and disadvantages of bilingualism. Forma function, 25(2), 99-114.

Best, J. R., Miller, P. H., \& Jones, L. L. (2009). Executive functions after age 5: changes and correlates. Developmental Review, 29(3), 180-200. http://doi.org/10.1016/j. dr.2009.05.002

Bialystok, E. (2017). The bilingual adaptation: how minds accommodate experience. Psychological Bulletin, 143(3), 233-262. http://doi.org/10.1037/bul0000099

Bialystok, E., Craik, F. I. M. (2010). Cognitive and linguistic processing in the bilingual mind. Current Directions in Psychological Science, 19(1), 19-23. http://doi. org/10.1177/0963721409358571

Bialystok, E., Craik, F. I. M., Klein, R., \& Viswanathan, M. (2004). Bilingualism, aging, and cognitive control: Evidence from the Simon task. Psychology and Aging, 19(2), 290303. http://doi.org/10.1037/0882-7974.19.2.290

Bialystok, E., Craik, F. I. M., \& Luk, G. (2008). Cognitive control and lexical access in younger and older bilinguals. Journal of Experimental Psychology: Learning Memory, and Cognition, 34(4), 858-873. http://doi.org/10.1037/0278-7393.34.4.859

Bialystok, E., Poarch, G., Luo, L., \& Craik, F. I. M. (2014). Effects of bilingualism and aging on executive function and working memory. Psychology and Aging, 29(3), 696705. https://doi.org/10.1037/a0037254

Dick, A. S., Garcia, N. L., Pruden, S. M. et al. (2019). No evidence for a bilingual executive function advantage in the ABCD study. Nature human behaviour, 3(7), 692701. http://doi.org/10.1038/s41562-019-0609-3

Emmorey, K., Luk, G., Pyers, J., \& Bialystok, E. (2008). The source of enhanced cognitive control in bilinguals: Evidence from bimodal bilinguals. Psychological Science, 19(12), 1201-1206. https://doi.org/10.1111/j.1467-9280.2008.02224.x

Fernandes, M. A., Craik, F. I. M., Bialystok, E., \& Kreuger, S. (2007). Effects of bilingualism, aging, and semantic relatedness on memory under divided attention. Canadian Journal of Experimental Psychology, 61(2), 128-141. https://doi.org/10.1037/cjep2007014

Haft, S. L., Kepinska, O., Caballero, J. N., Carreiras, M., \& Hoeft, F. (2019). Attentional fluctuations, cognitive flexibility, and bilingualism in kindergarteners. Behavioral Sciences, 9(5), 1-15. http://doi.org/10.3390/bs9050058

Holodnaya, M. A. (2004). Cognitive styles. St. Petersburg. Piter Publ. (In Russ.) 
Just, M. A., Carpenter, P. A. (1992). A capacity theory of comprehension: Individual differences in working memory. Psychological Review, 99(1), 122-149. https://doi.org/ 10.1037/0033-295x.99.1.122

Khotinets, V. Yu., Medvedeva, D. S. (2021). Peculiarities of speech-thinking activity in children with monolingualism and natural bilingualism. Psikhologicheskii zhurnal, 42(2), 25-35. https://doi.org/10.31857/S020595920014236-5 (In Russ.)

Khotinets, V. Yu., Salnova, S. A. (2020). Executive functions and their relationship with the development of Russian speech in bilingual and monolingual children. RUDN Journal of Psychology and Pedagogics, 17(3), 412-425. http://dx.doi.org/10.22363/23131683-2020-17-3-412-425 (In Russ.)

Kozhevnikova, O. V., Khotinets, V. Yu (2021). The subject of activity in situation of transition to digital world (Based on the materials of international scientific and practical conference "Actual Problems of Practical and Applied Psychology in the Current Socio-Cultural Situation") Psikhologicheskii zhurnal, 42(2), 131-134. https://doi.org/ 10.31857/S020595920014222-0 (In Russ.)

Li, P., Farkas, I. (2002). A self-organizing connectionist model of bilingual processing. In R. Heredia \& J. Altarriba (eds.), Advances in psychology: Vol. 134. Bilingual sentence processing (pp. 59-85). North-Holland/Elsevier Science Publishers. https://doi.org/ 10.1016/S0166-4115(02)80006-1

Li, P., Zhao, X., \& MacWhinney, B. (2007). Dynamic self-organization and early lexical development in children. Cognitive Science, 31(4), 581-612. https://doi.org/10.1080/ 15326900701399905

Lynn, R. (1999). Sex differences in intelligence and brain size: A developmental theory [Editorial]. Intelligence, 27(1), 1-12. https://doi.org/10.1016/S0160-2896(99)00009-4

Medvedeva, D. S., Khotinets, V. Yu. (2018). Development of speech activities of junior bilingual schoolchildren by means of cultural discourse. In V. V. Znakov \& A. L. Zhuravlyov (eds.), Psychology of a person as a subject of knowledge, communication and activity (pp. 1820-1827). Moscow Institute of Psychology of Russian Academy of Sciences. (In Russ.)

Medvedeva, D. C., Khotinets, V. Yu., \& Vyatkin B. A. (2017). Non-equilibrium of integration and differentiation of speech functions in bilingual children in the period after preschool age. In A. L. Zhuravlyov \& V. A. Koltsova (eds.), Basic and applied research of modern psychology: results and development prospects (pp. 1354-1361). Moscow Institute of Psychology of Russian Academy of Sciences. (In Russ.)

Michael, E., Gollan, T. H. (2005). Being and becoming bilingual: Individual differences and consequences for language production. In J. F. Kroll \& A. M. B. de Groot (eds.), The handbook of bilingualism: Psycholinguistic approaches (pp. 389-407). Oxford University Press.

Nikolaeva, E. I., Vergunov, E. G. (2017). Executive functions and their development in ontogenesis. Theoretical and Experimental Psychology, 10(2), 62-81. (In Russ.)

Rosen, V. M., Engle, R. W. (1997). The role of working memory capacity in retrieval. Journal of Experimental Psychology: General, 126(3), 211-227. https://doi.org/10.1037/ 0096-3445.126.3.211

Samuel, S., Roehr-Brackin, K., Pak, H., \& Kim, H. (2018). Cultural effects rather than a bilingual advantage in cognition: a review and an empirical study. Cognitive science, 42(7), 2313-2341. https://doi.org/10.1111/cogs.12672

Schneider, L. B., Kozintseva, P. A. (2019). Cognitive development of early age preschoolers in the context of mono-and bilingualism. The European proceedings of social \& behavioural sciences, 583-591. https://doi.org/10.15405/epsbs.2019.07.76 
Struys, E, Duyck, W., \& Woumans, E. (2018). The role of cognitive development and strategic task tendencies in the bilingual advantage controversy. Frontiers in psychology, 9, 1-11. http://doi.org/10.3389/fpsyg.2018.01790

Veraksa, A. N., Gavrilova, M. N., \& Buhalenkova, D. A. (2019). Association between language development and executive functioning in preschool age. Psikhologicheskii zhurnal, 40(3), 64-76. http://doi.org/10.31857/S020595920004599-4 (In Russ.)

Yasyukova, L. A. (2008). Examining school readiness. Prediction and prevention of primary school problems: a set for general education schools and gymnasiums. St. Petersburg Imaton (In Russ.)

Zhou, B., Krott, A. (2016). Bilingualism enhances attentional control in non-verbal conflict tasks. Evidence from ex-Gaussian analyses. Bilingualism: Language and Cognition, 21(1), 162-180. https://doi.org/10.1017/s1366728916000869 